steroid lặp đi lặp lại tại phòng khám ngoại trú đã mang lại kết quả tốt hơn so với nội soi ống tuyến đơn độc trong điều trị viêm tuyến nước bọt không rõ nguyên nhân tái phát [7]. Cùng một loại kết quả sơ bộ đã được tìm thấy trong một nghiên cứu trên 22 bệnh nhân mắc hội chứng Sjögren và sưng các tuyến nước bọt chính [5]. Sử dụng Steroid trong ống tuyến cũng được đánh giá và nhận thấy có hiệu quả ở những bệnh nhân bị viêm tuyến mang tai tái phát ở tuổi vị thành niên được điêu trị bằng truyên dịch hydrocortisone qua ống thông được đặt trong ống tuyến mang tai [3], và trong một nghiên cứu về tuyến nước bọt bị ảnh hưởng bởi bệnh tự miễn được điêu trị bằng nội soi ống tuyến và tiêm hydrocortisone trong ống tuyến [2]. Delagnes và cộng sự (2016) quan sát thấy rằng việc sử dụng triamcinolone bơm rửa đồng thời với nội soi ống tuyến có liên quan đến việc giải quyết triệu chứng tốt hơn ở những bệnh nhân bị viêm tuyến nước bọt mà không có sỏi nước bọt [8].

\section{KẾT LUÂN}

Điêuu trị bảo tồn viêm tuyến nước bọt mang tai mạn tính bằng bơm rửa hệ thống ống tuyến, có kểt hợp với các chất chống viêm, kháng khuẩn có hiệu quả cao, với kết quả cái thiện chỉ số VAS rõ rệt so với trước điều trị và tỷ lệ tái phát thấp.

\section{TÀI LIẸU THAM KHẢO}

1. Antoniades D, Harrison JD, Papanayotou $P$, et al. Treatment of chronic sialadenitis by intraductal penicillin or saline. J Oral Maxillofac Surg. 2004;62 (4):431-4. doi: 10.1016/j.joms.2003.07.007

2. Shacham $R$, Puterman $M B$, Ohana $N$, et al. Endoscopic treatment of salivary glands affected by autoimmune diseases. J Oral Maxillofac Surg. 2011; 69(2):476-481. doi: 10.1016/ j.joms.2010.10.002

3. Roby BB, Mattingly J, Jensen $E L$, et al. Treatment of juvenile recurrent parotitis of childhood: an analysis of effectiveness. JAMA Otolaryngol Head Neck Surg. 2015;141(2):126-9. doi: 10.1001/jamaoto.2014.3036

4. Johanna Jokela, Aaro Haapaniemi, Antti Mäkitie, Riitta Saarinen. Sialendoscopy in treatment of adult chronic recurrent parotitis without sialolithiasis. European Archives of OtoRhino-Laryngology. 2018; 275 (3):775-781. doi: 10.1007/s00405-017-4854-7

5. Capaccio $P$, Canzi $P$, Torretta $S$, et al. Combined interventional sialendoscopy and intraductal steroid therapy for recurrent sialadenitis in Sjogren's syndrome: results of a pilot monocentric trial. Clin Otolaryngol. 2018;43(1):96102. doi: 10.1111/coa.12911

6. Baurmash HD. Chronic recurrent parotitis: a closer look at its origin, diagnosis, and management. J Oral Maxillofac Surg. 2004; 62 (8):1010-1018. doi: 10.1016/j.joms.2003.08.041

7. Capaccio P, Torretta S, Di Pasquale D, Rossi V, Pignataro L. The role of interventional sialendoscopy and intraductal steroid therapy in patients with recurrent sine causa sialadenitis: a prospective cross-sectional study. Clin Otolaryngol. 2017;42(1):148-155. doi: 10.1111/coa.12681

8. Delagnes EA, Aubin-Pouliot $A$, Zheng $M$, et al. Sialadenitis without sialolithiasis: prospective outcomes after sialendoscopy-assisted salivary duct surgery. Laryngoscope. 2017;127(5):10731079. doi: 10.1002/lary. 26308

\title{
PHÂN LOAI MÔ BÊNH HỌC SARCOM XƯƠNG NGUYÊN PHÁT THEO PHÂN LOAI CỦA TỔ CHỨC Y TẾ THẾ GIỚI (WHO) NĂM 2013 VÀ TİM HIỂU MỐI LIÊN QUAN VỚI TIÊN LƯợNG BỆNH
}

\section{TÓM TẮT}

Mục tiêu: Phân loai mô bệnh học sarcom xương nguyên phát và tìm hiểu mối liên quan với tiên lượng bệnh trên các bệnh nhân sarcom xương tại bệnh viện K. Đối tượng và phương pháp nghiên cứu: Kết hợp hồi cứu và tiến cứu trên 123 bệnh nhân được chẩn đoán sarcom xương và điều trị tại bệnh viện K.

\footnotetext{
${ }^{1}$ Bênh viện $K$

${ }^{2}$ Trường Đại hoc Y Hà Nôi

Chịu trách nhiệm chính: Phạm Thị Hân

Email: phamthihan.bvk@gmail.com

Ngày nhận bài: 24.6.2021

Ngày phản biên khoa học: 23.8.2021

Ngày duyệt bài: 27.8.2021
}

\section{Phạm Thị Hân ${ }^{1}$, Tạ Văn Tờ ${ }^{1,2}$}

Kết quả: Trong 123 trường hợp, các típ mô bệnh học độ cao chiếm chủ yếu với $98,37 \%$ số ca. Trong số đó, dưới típ nguyên bào xương chiếm tỷ lệ cao nhất là $54,47 \%$. Tiếp đến là típ nguyên bào xớ, nguyên bào sụn và các típ mô học độ cao khác. Các típ mô học độ thấp chỉ chiếm $1,63 \%$. Sự khác biệt giữa các nhóm có ý nghĩa thống kê với $\mathrm{p}<<0,05$. Xác suất sống sót chung sau 5 năm là $41,7 \%(95 \% \mathrm{CI}=0,33-0,54)$. Phân típ mô bệnh học không có mối liên quan có ý nghĩa thống kê với xác suất sống sót $(p>0,05)$.

Ti̛ khóa: Sarcom xương nguyên phát, típ mô bệnh học, xác suất sống sót.

\section{SUMMARY \\ CLASSIFYING PRIMARY OSTEOSARCOMAS ACCORDING TO 2013 WORLD HEALTH}




\section{ORGANISATION'S CLASSIFICATION OF TUMOURS OF SOFT TISSUE AND BONE AND EVALUATING RELATIONSHIPS WITH SURVIVAL PROBABILITY}

Objectives: Classifying primary osteosarcomas according to the 2013 World Health Organisation classification of tumours of soft tissue and bone and evaluating relationships with survival probability. Subjects and methods: A retrospective and prospective study was performed in 123 patients with primary osteosarcoma and treated in $\mathrm{K}$ hospital. Results: 123 patients with primary osteosarcomas: high-grade subtypes were prominent with the percentage of $98.37 \%$ of all. In this group, osteoblastic osteosarcoma was highest with $54.47 \%$. Following by chondroblastic osteosarcoma, fibroblastic osteosarcoma. Low grade osteosarcoma confined to $1,63 \%(p<0,05)$. 5 year survival rate was $41,7 \%$ $(95 \% \mathrm{CI}=0,33-0,54)$. The relationship between histologic subtypes and survival rates was not statistical significant $(p>0,05)$.

Keywords: Primary osteosarcoma, histology subtypes, survival rate.

\section{I. ĐĂT VẤN ĐỀ}

Ung thư hiện đang là một vấn đề thời sự, không chỉ ở Việt Nam mà trên toàn thế giới. Theo ghi nhận ung thư toàn cầu, số ca ung thư mới mắc hiện đang tăng nhanh ở cả hai giới. Tần suất mới mắc trung bình ở nữ năm 2018 là 182,6/100 000 dân, cao hơn năm 2012 là hơn $35 \%$ (so với $134,9 / 100000$ dân) và cao hơn gần gấp đôi so với số lượng thống kê năm 2000 (101,6/100 000 dân). Ớ nam giới, tình trạng bệnh cũng tương tự. Số lượng mới mắc thống kê được năm 2018 là 218.6/100 000 dân so với năm 2012 là 181,3/100 000 và so với $141,6 / 100$ 000 trong năm 2000. Trong số này, các sarcom xương không phải là những ung thư hay gặp, chỉ chiếm $0,2 \%$ số trường hợp ung thư [1]. Tuy vậy, sarcom xương lại là ung thư phổ biến thứ 3 ở tuổi vị thành niển và chiếm khoảng $56 \%$ các u xương [2].

Số lượng bệnh nhân sarcom xương sống sót tăng đáng kể trong vòng 30 năm trở lại đây, phần lớn do những tiến bộ trong hóa trị liệu. Trước kỷ nguyên của liệu pháp hóa trị, $80-90 \%$ bênh nhân sarcom xướng có di căn và chết do bệnh mặc dù đã phẫu thuật kiểm soát tốt tổn thương tại chố. Tuy nhiên, trong liệu pháp điều trị đa mô thức, phẩu thuật vẫn giữ vai trò trung tâm. Các sarcom xương độ thấp như sarcom xương típ cận vỏ không dùng hóa trị một cách thường quy do $u$ ít có nguy cơ di căn xa. Bằng liệu pháp điều trị hiện đại ngày nay, khoảng $2 / 3$ bệnh nhân sarcom xương ở chi không di căn tại thời điểm chẩn đoán có thời gian sống thêm dài. Khoảng $50 \%$ bênh nhân có di căn giới han ở phổi có thể chữa khỏi bênh. Thời gian sống thêm không tái phát dài có thể lên đến $25 \%$ trên tổng số đối với những bệnh nhân sarcom xương di căn [3].

Để xem xét phân bố các loại sarcom xương cũng như mối liên quan giữa các típ mô bệnh học với khả năng sống còn sau điều trị, chúng tôi tiến hành nghiên cứu này với mục đích: (1) Phân loại mô bệnh hoc sarcom xương nguyên phát theo phân loại của Tổ chức Y tế Thế giới (WHO) năm 2013; (2) Đánh giá mối liên quan giữa mô bệnh học và tiên lượng bệnh.

\section{II. ĐỐI TƯƠNG VÀ PHƯƠNG PHÁP NGHIÊN CỨU}

2.1 Đối tượng nghiên cứu: 123 bệnh nhân (BN) được chẩn đoán là sarcom xương nguyên phát tại Bệnh viện $K$ từ tháng $1 / 2015$ đên $12 / 2018$

2.2 Phương pháp nghiên cứu: Phương pháp nghiên cứu là mô tả cắt ngang, kết hợp hồi cứu và tiến cứu. Khai thác hồ sơ, bệnh án; đọc và phân loại các bệnh phẩm theo phân loại về u mô mềm và xương của WHO năm 2013; Phân loại giai đoạn theo Enneking 1983. Tất cả các ca bệnh trong nghiên cứu đều lấy lại phim để đọc. Trước tiên là phim $X Q$, kết hợp thêm phim $C T$ và MRI. Những ca không tìm thấy phim XQ sẽ dùng hình ảnh của $C T$ và MRI kết hợp. Chúng tôi ghi lại thông tin điều trị của bệnh nhân và tình trạng sống còn tại thời điểm tính đến tháng 12 năm 2020.

Tiếp đến, chúng tôi phân tích tỉ lệ sống còn của bệnh nhân. Phân tích đơn biến và đa biến nhằm tìm mối liên quan giữa xác suất sống sót với các biến số, từ đó làm rõ mối liên quan giữa xác suất sống sót với phân típ mô bệnh học.

2.3 Phân tích và xử lý số liệu. Số liệu được phân tích bằng ngôn ngữ thông kê R 4.0.2

- Thống kê tần số, tần suất

- Các phương pháp kiểm định bao gồm: so sánh một hoặc nhiêu tỉ lệ, Fisher exact, t-test với mức ý nghĩa thống kê 0,05

- Phân tích tiên lượng sống còn bằng phương pháp Kaplan - Meier

\section{KẾT QUẢ NGHIÊN CứU}

3.1 Một số đặc điểm chung của đối tượng nghiên cứu. 123 bệnh nhân trong nghiên cứu có những đặc điểm chung sau

Bảng 3.1 Một số đặc điểm chung của các đôî tượng nghiên cứu

\begin{tabular}{|c|c|c|c|c|}
\hline Giá trị & Đặc điểm & Số trường hợp & \% & P overall \\
\hline & Tuối trung bình: $21,4(12,9)$ & tuối. Tuối nhỏ nhất: 6 tuối; Tuối lớn nhất: 68 tuô̂i \\
\hline
\end{tabular}


TẠP CHÍ Y HỌC VIẸT NAM TẬP 506 - THÁNG 9 - SÓ 2 - 2021

\begin{tabular}{|c|c|c|c|c|}
\hline \multirow{2}{*}{ Giới } & Nam & 69 & 57,0 & \\
\hline & Nữ & 54 & 43,0 & 0,18 \\
\hline \multicolumn{2}{|r|}{ T/gian biếu hiện t/chứng: 5.9 (22.7) tháng } & Min: 1 tháng; & \multicolumn{2}{|c|}{ Max: 224 tháng } \\
\hline \multirow{3}{*}{$\begin{array}{l}\text { Kích } \\
\text { thước u }\end{array}$} & KTTB: $11,8(6.20) \mathrm{cm}$ & Min: $1,00 \mathrm{~cm}$ & Max: $36 \mathrm{~cm}$ & \\
\hline & $\leq 8 \mathrm{~cm}$ & 38 & 30,89 & \multirow{2}{*}{$3,02036 \mathrm{E}-07$} \\
\hline & $>8 \mathrm{~cm}$ & 95 & 69,11 & \\
\hline \multirow{4}{*}{ Vị trí u } & X. cánh tay & 13 & 10,57 & \multirow{4}{*}{$7,08725 \mathrm{E}-12$} \\
\hline & X. đùi & 64 & 52,03 & \\
\hline & X. chày & 32 & 26,02 & \\
\hline & Các xương khác & 14 & 11,38 & \\
\hline \multirow{5}{*}{$\begin{array}{l}\text { Típ mô } \\
\text { bệnh học }\end{array}$} & Nguyên bào xương & 67 & 54,47 & \multirow{5}{*}{$9,45834 \mathrm{E}-21$} \\
\hline & Nguyên bào sụn & 12 & 9,76 & \\
\hline & Nguyên bào xơ & 19 & 15,45 & \\
\hline & Các típ mô hoc đô cao khác & 23 & 18,70 & \\
\hline & Các típ mô học độ thấp & 2 & 1,63 & \\
\hline \multirow{5}{*}{$\begin{array}{l}\text { Giai đoạn } \\
\text { Enneking }\end{array}$} & IA & 0 & 0 & \multirow{5}{*}{$<2.2 \mathrm{e}-16$} \\
\hline & IB & 2 & 1,6 & \\
\hline & IIA & 0 & 0 & \\
\hline & IIB & 100 & 81,3 & \\
\hline & III & 21 & 17,1 & \\
\hline
\end{tabular}

Nhận xét: Theo số liệu tại bảng 3.1 ta thấy tuổi trung bình trong nghiên cứu là 21,4 tuổi. Tuổi nhỏ nhất là 6 tuổi, tuổi lớn nhất là 68 tuổi. Tỷ lệ nam/nữ $\approx 1,28 / 1(p>0,05)$. Thời gian biểu hiện triệu chứng trung bình là 5,9 tháng. Kích thước u trung bình là $11,8 \mathrm{~cm}$. Trong đó kích thước $u>8 \mathrm{~cm}$ là $69,11 \%$ và nhóm $\leq 8 \mathrm{~cm}$ là $30,89 \%(p<0,05)$. Xương đùi hay gặp nhất với $52,03 \%$ bệnh nhân, tiếp đến là xương chày $(26,02 \%)$ và xương cánh tay $(10,57 \%)$. Các típ mô bệnh học độ cao chiếm $98,27 \%$ với các típ phổ biến là nguyên bào xương $(54,47 \%)$, nguyên bào xơ $(15,45 \%)$ và nguyên bào sụn $(9,76 \%)$. Các bệnh nhân nhập viện ở giai đoạn xâm lấn tại chỗ và tiến xa (IB, IIB và III) (100\%).

3.2 Mối liên quan giữa phân loại mô bệnh học với xác suất sống sót

3.3.1 Xác suât sông sót chung của các bệnh nhân trong nghiên cứu

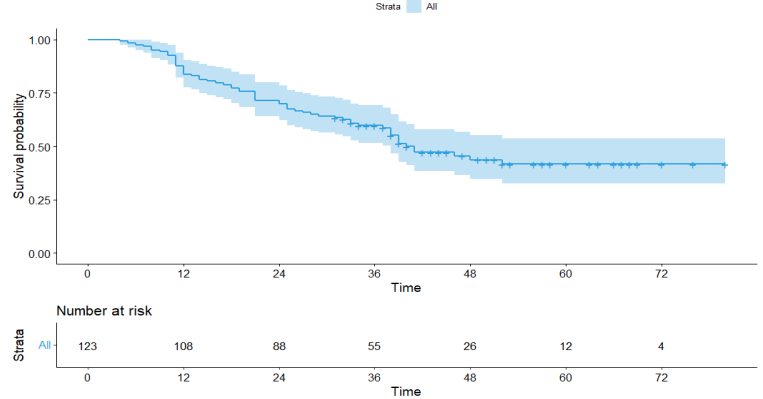

Biểu đồ 3.1: Xác suât sông sót chung của các bệnh nhân trong nghiên cứu

Nhận xét: Biểu đồ 3.1 cho chúng ta thây bệnh nhân sống sót chung sau 5 năm là $41,7 \%$.
Theo biểu đồ 3.3, khoảng thời gian tỷ lệ sống sót giảm mạnh nhất vào khảng năm thứ 2 (từ 12 đến 24 tháng), trong đó thời gian tỷ lệ sống sót giảm $1 / 2$ ở khoảng 24 tháng. Từ năm thứ 4 trở đi, số bệnh nhân tữ vong chậm lại và khả năng sống sót của bệnh nhân duy trì ổn định ở mức khoảng 40\%.

3.3.2 Môi liên quan phân loại típ mô bệnh học với xác suất sống sót

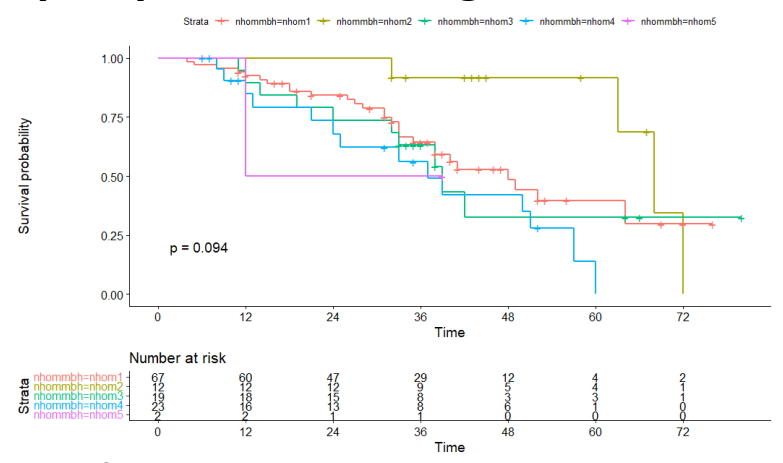

Biểu đồ 3.2. Môi liên quan giữa xác suât sông sót với phân típ mô bênh hoc

Nhân xét: Biểu đồ 3.2 so sánh xác suất sống còn giữa các nhóm mô bệnh học theo thời gian. Theo đó, xác suất sống còn của sarcom xương nguyên bào sụn cao hơn so với nhóm còn lại và sarcom xương nguyên bào xơ có xác suất sống còn về lâu dài thấp hơn. Tuy nhiên, sự khác biệt này không có ý nghĩa thống kê $(p>0,05)$. Theo biến đổi của thời gian, xác suất sống sót của các nhóm mô bệnh học giảm mạnh nhất vào khoảng từ 1 đến 4 năm. Thời điểm xác suất sống sót còn $50 \%$ ở các nhóm nguyên bào xương, nguyên 
bào xơ, các típ độ cao khác ở khoảng thời gian 3,5 năm. Tại thời điểm 5 năm, xác suất sống sót của týp nguyên bào sụn là $62 \%$, týp nguyên bào xương là $45 \%$, típ nguyên bào xơ là $35 \%$, các týp độ cao khác là $40 \%$, với sarcom xương độ thấp là $50 \%$.

3.3 Mối liên quan giữa độ mô học với xác suất sống sót

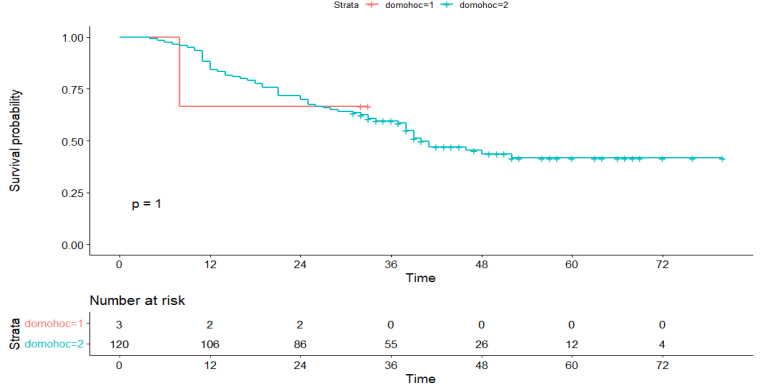

Biểu đổ 3.3: Môi liên quan giữa xác suât sống sót với độ mô học

Nhân xét: Mắc dù các dưới típ mô bênh hoc đã ngầm phân đồ mô học nhưng chúng tồi muốn làm rõ hơn mối liên quan giữa độ mô học và xác suất sống sót. Biểu đồ 3.3 so sánh xác suất sống còn giữa hai nhóm có độ mô học thấp và cao. Nhìn chung, nhóm có độ mô học thấp có xác suất sống còn cao hơn so với nhóm có độ mô học cao. Tuy nhiên, sự khác biệt không có ý nghĩa thống kê $(p>0,05)$. Thêm vào đó, số lượng bênh nhân sacôm xương độ thấp ít ( 2 bềnh nhân) và cõ mẫu ít (123 bệnh nhân) nên biểu đồ so sánh này có thể không đại diện. Dù vậy, theo biểu đồ dự đoán thì xác suất sống sót của cả hai nhóm giảm manh từ sau năm thứ nhất đến năm thứ 3. Thời điểm xác suất sống sót của nhóm độ mô học cao còn lại $50 \%$ vào khoảng 3,5 năm. Tại thời điểm 5 năm, xác suất sống sót của nhóm độ mô học cao vào khoảng $40 \%$.

\section{BÀN LUẬN}

Sarcom xương là u ác tính nguyên phát hay gặp nhất của xương. $U$ đặc trưng bởi mô dạng xương (xương chưa trưởng thành) tạo thành từ các tế bào ác tính [2]. Sarcom xương hiếm gặp hơn so với ung thư biểu mô, với khoảng $900 \mathrm{ca}$ mỗi năm tại Mỹ [4]. Phần lớn những bệnh nhân này là trẻ nhỏ và vị thành niên. Trong lứa tuổi từ 15 - 29 tuổi. U xương chiếm khoảng 3\% tất cả các loại u và sarcom xương chiếm $1 / 2$ trong số đó.

Hầu hết sarcom xương có độ ác tính cao và thường gặp ở các chi dài. Những vị trí hay găp nhất là xương đùi với $52,03 \%$ số ca, xương chày $26,02 \%$ ca và xương cánh tay $10,57 \%$ ca $(p<0,05)$. Các nghiên cứu cũng thống nhất ở thứ tự thường gặp của sarcom (theo thứ tự giảm dần) là xương đùi, xương chày, xương cánh tay. Như vậy u thường xuất hiện ở những xương tăng trưởng manh về chiều dài. Do sarcom xuất hiên nhiêu nhất ở lứa tuổi vị thành niên, khi đĩa phát triển tăng trưởng mạnh do đó những xương dài dễ gặp sarcom hơn những vị trí khác.

Số liệu bảng 3.1 cho thây $98,37 \%$ bệnh nhân là sarcom xương độ cao. Trong số sarcom độ cao, các típ phổ biến nhất là nguyên bào xương với $54,47 \%$ số ca. Típ nguyên bào xơ chiếm $15,45 \%$ và nguyên bào sụn với $9,76 \%$ bệnh nhân. Những típ sarcom xương độ cao khác cũng gặp trong nghiên cứu gồm sarcom xương tế bào nhỏ, típ dãn mạch, giống nguyên bào xớ, giàu tế bào khổng lồ hủy cốt bào, sarcom thông thường độ cao không xếp loại. 2/123 ca là sarcom xương trung tâm độ thấp, chiếm 1,63\%.

Tổng hợp mô hình sarcom xương trong 30 năm, Mirabello [5] cũng thấy mô hình phân bố tương tự. Tuy nhiên, trong nhiều phiếu kết quả hiện nay, các bác sĩ giải phẫu bệnh chỉ đề kết quả là "sarcom xương", điều này chưa phản ánh được bản chất của u, mức độ nghiêm trọng, tiên lượng và chưa thể hiện được sự cập nhật trong phân loại chẩn đoán u.

Tính kết quả sống thêm bằng phương pháp ước lượng sống thêm theo Kaplan-Meier. Thời gian sổng thêm tính từ thời điểm bắt đầu can thiệp điều trị đến khi bệnh nhân tử vong hoặc có thông tin cuối cùng. Do đây là nghiên cứu về giải phẫu bệnh nên chúng tôi chỉ đánh giá xác suất sống sót chung, không đánh giá sống thêm không bệnh hay sống thêm không biến cố.

Xác suất sống thêm sau 5 năm của nghiên cứu là $41,7 \%$. So với kết quả của Võ Tiến Minh [6] nghiên cứu trên những bệnh nhân chỉ phẫu thuật đơn thuần có xác suất là $34,3 \%$. Tác giả Trần Văn Công [7] nghiên cứu về hóa trị bổ trợ nên xác suất sống sót cao với $62,6 \%$, tương đương với các nghiên cứu về hóa trị của các tác giả nước ngoài như Bielack [8] và Bacci [3].

Nhìn lại nghiên cứu này, do chúng tôi thống kê tất cả các nhóm bệnh nhân (nhiều giai đoạn bênh, điều trị hoặc không, nhiều phương pháp điều trị khác nhau) nên tỷ lệ sống sót sau 5 năm của các bệnh nhân trong nghiên cứu có thấp hơn so với những nghiên cứu trên các bệnh nhân có hóa trị $[3,7,8]$ nhứng cao hơn so với nghiên cứu chỉ có phẫu thuật đơn thuần [6].

Tìm hiểu sâu hợn về mối liên quan giữa xác suất sống sót và típ mô bệnh học, chúng tôi thấy rằng tại thời điểm 5 năm, xác suất sống sót của týp nguyên bào sụn là $62 \%$, týp nguyên bào 
xương là $45 \%$, típ nguyên bào xơ là $35 \%$, các týp độ cao khác là $40 \%$, với sarcom xương độ thấp là $50 \%(p>0,05)$. Kết quả nghiên cứu này tương tự nhận xét của Hauben [9] khi nghiên cứu trên 570 bệnh nhân sarcom xương trong một thử nghiệm lâm sàng lớn ở Châu Âu.

Số bệnh nhân sarcom xương độ thấp của chúng tôi chỉ có 2 bệnh nhân nên không đủ số lượng để có thể đưa ra nhận xét. Nhưng tham chiếu với $\mathrm{y}$ văn thì có thể nhận thấy rằng các sarcom xương độ thấp có tỷ lệ sống sót cao hơn so với các sarcom xương độ cao.

\section{KẾT LUẬN}

Với 123 bệnh nhân trong nghiên cứu, các típ mô học độ cao chiếm tỉ lệ $98,37 \%$. Thứ tự các típ mổ bệnh học phổ biến nhất, theo chiều giảm dần, là típ nguyên bào xương $(54,47 \%)$, nguyên bào $x$ ơ $(154,5 \%)$ và nguyên bào sụn $(9,76 \%)$ $(p<0,05)$. Các típ mô học có mối liên quan đến xác suất sống còn, nhưng sự khác biệt không có ý nghĩa thống kê $(p>0,05)$.

\section{TÀI LIÊU THAM KHẢO}

1. Ferlay J, Colombet $M$, Soerjomataram $I$, Mathers $C$, Parkin $D$, Piñeros $M$, et al. Estimating the global cancer incidence and mortality in 2018: GLOBOCAN sources and methods. International journal of cancer. 2019;144(8):1941-53.

2. Bridge J, Hogendoorn P, DM C, Bridge JA, CW P, Fletcher CD. WHO classification of tumours of soft tissue and bone: International Agency for Research on Cancer; 2013.
3. Bacci G, Longhi A, Versari $M$, Mercuri $M$, Briccoli A, Picci P. Prognostic factors for osteosarcoma of the extremity treated with neoadjuvant chemotherapy: 15-year experience in 789 patients treated at a single institution. Cancer: Interdisciplinary International Journal of the American Cancer Society. 2006;106(5):1154-61.

4. Ries L. SEER cancer statistics review, 19752002. http://seer cancer gov/csr/1975_2002/. 2002.

5. Mirabello L, Troisi RJ, Savage SA. Osteosarcoma incidence and survival rates from 1973 to 2004: data from the Surveillance, Epidemiology, and End Results Program. Cancer: Interdisciplinary International Journal of the American Cancer Society. 2009;115(7):1531-43.

6. Minh VT. Nhận xét về đă̆c điểm lâm sàng, $X$ quang, mô bệnh học và kết quả điều trị ung thư xương nguyên phát tại bệnh viện K. Hà Nội: Trường Đại học Y Hà Nội; 2000.

7. Công TV. Nghên cứu điêu trị sacôm tạo xương giai đoạn II bằng phẫu thuật và hóa chất phác đồ doxorubicin, cisplatin tại Bệnh viện K. Hà Nội: Đại hoc Y Hà Nội; 2009.

8. Bielack SŚ, Kempf-Bielack B, Delling Gn, Exner GU, Flege S, Helmke K, et al. Prognostic factors in high-grade osteosarcoma of the extremities or trunk: an analysis of 1,702 patients treated on neoadjuvant cooperative osteosarcoma study group protocols. Journal of clinical oncology. 2002;20(3):776-90.

9. Hauben E, Weeden S, Pringle J, Van Marck E, Hogendoorn P. Does the histological subtype of high-grade central osteosarcoma influence the response to treatment with chemotherapy and does it affect overall survival? A study on 570 patients of two consecutive trials of the European Osteosarcoma Intergroup. European Journal of Cancer. 2002;38(9):1218-25.

\section{ĐẶC ĐIỂM SANG CHẤN TÂM LÝ Ở NGƯờI BÊNH RỐI LOẠN LOẠN THẦN CẤP VÀ NHẤT THỜ'I}

\section{TÓM TẮT}

Mục tiêu: Mô tả đặc điểm sang chấn tâm lý ở người bệnh rối loạn loạn thần cấp và nhất thời. Đối tượng và phương pháp: Sử dưng phương pháp mô tả cắt ngang, phân tích đặc điểm sang chẩn tâm lý bằng phỏng vấn trực tiếp bệnh nhân và người nhà bênh nhân được điều tri nội trú tại Viên Sức khỏe Tâm thần- Bệnh viện Bạch Mai. Kết quả: 57 bệnh nhân có sang chấn tâm lý trong số 81 bệnh nhân rối loạn loạn

\footnotetext{
${ }^{1}$ Viện Sức khoẻ Tâm thần - Bệnh viện Bạch Mai, ${ }^{2}$ Trường Đai hoc Y Hà Nôi

Chịu trách nhiệm chính: Đoàn Thị Huệ

Email: doanthihue@hmu.edu.vn

Ngày nhận bài: 25.6.2021

Ngày phản biên khoa hoc: 23.8.2021

Ngày duyệt bài: 30.8.2021
}

Đoàn Thị Huệ ${ }^{1}$, Dương Minh Tâm ${ }^{1,2}$

thần cấp và nhất thời chiếm tỷ lệ $70,4 \%$. Phân tích 57 bệnh nhân có sang chấn tâm lý chúng tôi thấy: khó khăn về kinh tế là sang chấn tâm lý gặp nhiêu nhất, chiếm $29,6 \%$, không có bệnh nhân nào mà nghỉ hưu là sang chấn tâm lý. Chủ yếu sang chấn tâm lỳ xảy ra trước khi bị bệnh trên 2 tuần, chiếm $54,3 \%$. Phần lớn sang chấn tâm lý có cường độ và ý nghĩa ở mức độ vừa $(50,6 \%$ và $58,0 \%)$. Kểt luận: Rối loạn loạn thần cấp và nhất thời có tỳ lệ cao các sang chấn tâm lý, phân lớn là các sang chấn về vấn đề kinh tế khó khăn, cường độ và ý nghĩa sang chấn chủ yếu ở mức độ vừa phải.

Từ khóa: Rối loạn loạn thân cấp và nhất thời, sang chấn tâm lý

\section{SUMMARY \\ CHARACTERISTICS OF PSYCHOLOGICAL TRAUMA IN PATIENTS WITH ACUTE AND TRANSIENT PSYCHOSIS}

